\title{
The Three Seas Initiative as a Political Challenge for the Countries of Central and Eastern Europe
}

\author{
MAREK GÓRKA
}

\section{$\$$ sciendo}

Politics in Central Europe (ISSN: 1801-3422)

Vol. 14, No. 3

DOI: 10.2478/pce-2018-0018

\begin{abstract}
The Three Seas Initiative (TSI) is an informal association that focuses mainly on the economic integration of EU member states through the cooperation of specific sectors. It is meant to strengthen the single market and bonds among countries in Central and Eastern Europe. It also seeks to reduce developmental differences between these countries and the older EU member states. This study explores the background of the TSI, which was jointly conceived by the presidents of Poland and Croatia with the goal of strengthening ties among countries in the area between the Black, Baltic and Adriatic seas. The association brings together 12 states across Central and Eastern Europe and the Balkans: Poland, the Czech Republic, Slovakia, Hungary, Lithuania, Latvia, Estonia, Croatia, Slovenia, Bulgaria, Romania and Austria. As well as enhancing their political ties, it aims to develop cross-border cooperation and implement macro-regional projects. The analysis highlights both the diverging interests of the TSI countries and their common predicament. These states are connected by the fact that they stand to lose the most from the two-speed Europe idea that some Western politicians have imposed. They are also at a clear disadvantage when it comes to infrastructure investments. In the past, the European Union has emphasized East-West cooperation and overlooked the North-South communication and energy corridors. The Three Seas Initiative founders are trying to determine the best form of cooperation for the Central and Eastern Europe region.
\end{abstract}

Keywords: security policy, Three Seas Initiative, Visegrad Group, Central Europe, European integration 


\section{Introduction}

In 2016, Croatia and Poland led the creation of the Three Seas Initiative (TSI), which brings together 12 European countries from the Baltic to the Black and Adriatic seas. These states - Poland, Lithuania, Estonia, Latvia, Hungary, Austria, Slovenia, Croatia, the Czech Republic, Slovakia, Romania and Bulgaria - are considering undertaking joint projects related to innovation and the development of economic infrastructure (Kauffmann 2017).

When US President Donald Trump visited Poland during the second TSI summit in 2017, a question arose about whether this geopolitical association might be a key reference point in Euro-Atlantic economic and political relations. There has also been a broad discussion about the initiative's capacity to benefit participating countries. In the ongoing debate, many have directly questioned the chances of this political venture's success. There are also doubts about whether the states in this region - which extends from Lithuania to the Balkans and Romania - share a sense of common destiny.

The current Intermarium (literally "between seas") project can be understood in various ways. From the points of view of both Russia and the West, these states are located on the edge of the sphere of influence of one side or the other. As such, there is a question about whether they have sufficient skills, diplomatic infrastructure and security strategies to negotiate the complex and often unclear system of international relations.

This article sets out to understand the challenges faced by each of the 12 states engaged in this political project. In particular, it explains and analyses the position of each country with reference to regional cooperation, European integration and domestic policies. This work is done with the aim of determining whether the Three Seas Initiative has the potential to become a political and economic alliance that also develops a common foreign and security policy. This question is especially important at a time when Polish plans to create a new "alliance" are seen as incomprehensible by some European allies. Some are questioning the desire to establish an agreement that remains to some extent outside the European Union, NATO and Visegrad Group.

\section{History and the present}

Current political issues are usually bound up with historical events and so in order to understand why some European countries are averse to, and have distanced themselves from, the Three Seas Initiative, we need to consider some history. This historical context can explain what are often complex problems in contemporary international politics. The Three Seas Initiative is the modern embodiment of a proposal known in Poland before World War II as Międzymorze (the Intermarium). Introduced by Józef Piłsudski, a Polish leader of the interwar 
period, that plan concerned the creation of a confederation to be led by Poland that would link up states in the area of the Adriatic, Baltic and Black seas. The cooperation among these countries was supposed to promote the independence of Central Europe and provide a counterbalance to the power of Soviet Russia and Germany. Nevertheless, the project was never implemented, in part because of conflicting national interests. French diplomats torpedoed the plan and Lithuania saw it as a threat to national independence. Czechoslovakia did not want to participate in an alliance with Poland while Hungary and Romania were ready to cooperate with Poland but not with each other (Gera 2017).

Almost 80 years later, the Intermarium idea has resurfaced. The inaugural Three Seas Initiative summit was held in Dubrovnik, Croatia, in August 2016 (Cabada 2018: 8-9). Today the initiative represents a forum for leaders and high-ranking officials from the 12 participating European countries. In tracing the TSI's origins, it is also worth noting an earlier informal trilateral meeting which took place during the United Nations General Assembly in New York in September 2014. Croatia was the initiator of that meeting (Kořan - Wiśniewski Strážay 2017).

The second TSI summit, held in Warsaw on 6 July 2017, was notable for the presence of President Trump, whose speech clearly conveyed America's support for the project. Representatives of the 12 member countries took part. They included the presidents of ten states in Central and Eastern Europe: Bulgaria, Croatia, Estonia, Lithuania, Latvia, Poland, Romania, Slovakia, Slovenia and Hungary. The leaders of the Czech Republic and Austria were absent.

The dominant theme of both TSI summits was the need to develop connected infrastructure along the North-South axis where the absence of these networks is clearly affecting energy, economy and security policies. Perfectly encapsulating the problem was the lack of economic and communications connections between Croatian and Romanian seaports (Corneliu-Aurelian 2017).

The second TSI summit also tackled an important question: Could countries from outside the European Union be included in the Intermarium project as observers or in some other role? Supporters of this idea argued that including these states would not only promote economic innovation and strengthen economic relations but also be a stabilising force politically (Corneliu-Aurelian 2017).

\section{Goals and tasks of the Three Seas Initiative}

The Three Seas Initiative was established by EU member states with the goal of better integrating the countries on the North-South axis by connecting infrastructure across the energy, transport and telecommunications sectors. The initiative seeks to overcome the traditional division of Europe into East and West. It should also increase connections inside the EU single market (Wiśniewski 2017: 55-64). 
The economic situation of Central and Eastern Europe is the motivation for this alliance. These economic problems are attributed to the fact that most of the region's strategic infrastructure, including road and rail infrastructure, runs along the East-West corridor, a situation partly due to Germany's economic dominance. Communications routes, gas pipelines, railways and highways all extend from East to West, and it is, thus, in the region's interest to establish North-South counterparts.

The project is also said to reflect the current stage of Central and Eastern Europe's economic and technological transformation. Insufficient infrastructure between countries including Poland and Slovakia, and Bulgaria and Romania, points to the need for modernisation (MacDowall 2013). Investing in better communication and international cooperation could serve to level development opportunities across different EU regions. This should, in turn, improve competitiveness (President of the Republic of Poland 2017).

The TSI aims to strengthen cooperation not only at a political but also at a commercial level across the EU single market. Member countries have set themselves the target of diversification, particularly when it comes to gas supplies, in order to improve energy security in the region. This process is directly linked to US diplomatic actions on the liquefied natural gas (LNG) global market. In this context, it should ensure the US's presence in Central and Eastern Europe in line with President Trump's statements.

The initiative's message is, however, not limited to the energy industry: it also applies to other sectors that could benefit from favourable conditions for cooperation and commercial development. It will, for example, create cooperation opportunities for the providers of the telecommunications and digital technologies required for infrastructure projects (Wiśniewski 2017: 55-64).

Poland has linked its economic recovery to the move to improve transport and energy networks on the North-South axis and supplement better developed East-West connections. The development of these main communications routes also accords with a key principle of European policy: the strengthening of EU cohesion. To this end, the construction of two access corridors to Polish ports the Via Baltica and Via Carpatia routes - should connect the Baltic states with the Balkans (Gniazdowski 2017: 105-108).

Plans are also afoot to improve digital infrastructure in the region, a task that is becoming increasingly urgent. State-of-the-art industry calls for new forms of connection. All these changes are clearly in the interest of Western European enterprises: the region will have increased appeal to major investors coming from both within and outside the EU. 


\section{The Three Seas Initiative vs. the European Union?}

The relationship between the Three Seas Initiative and the EU is the focus of much discussion. It is difficult to agree with those who claim the initiative is an attempt to break up the EU from the inside. If the goal set for the Three Seas Initiative - development of energy, transport and digital infrastructure is achieved, then this will enhance European integration. As was stressed in a declaration at the Warsaw summit, the TSI is a flexible presidential forum; it is simply meant to provide political support for more effective cooperation among governments, businesses and non-governmental organisations that are interested in strengthening regional ties (President of the Republic of Poland 2017).

The TSI currently provides a platform for 12 presidencies but it has little impact on the foreign policy of member states. As such, it may be understood as a geopolitical and economic initiative for EU member states (Milewski 2017: 82-93). The founding countries have emphasised that their project does not conflict with the European Union. Rather it seeks to supplement the existing approach to economic and infrastructure development in Central and Eastern Europe, a region where the need for major development stimuli is widely recognised by politicians (Corneliu-Aurelian 2017). The initiative is seen as an important next step to ensure the more dynamic development of selected projects in the EU. It is not an intergovernmental organisation designed to replace or undermine any EU institution but a group seeking to improve bilateral or multilateral sub-regional relations at EU level (Milewski 2017: 82-93).

Politicians from this region have emphasised that it needs to have a stronger voice in the EU: these states, they say, are no longer content to serve as apprentices to Western countries; they have their own ideas that they wish to pursue (Ruszkowski 2017: 115-137). In this context, as Croatian President Kolinda Grabar-Kitarović notes, the TSI is an informal political forum where Central European countries can pursue their goal of strengthening European ties and economic cooperation by building transport and energy infrastructure and creating digital technologies (Pavlovets 2017). During the Dubrovnik meeting, TSI country representatives made clear the initiative's wish to strengthen the EU single market. There can be no doubt that this dimension of integration is one of the greatest achievements of the European Community. However, there remains a need to upgrade existing infrastructure and invest in new physical connections between member states - including along the North-South axis. This is the guiding goal of the Three Seas Initiative and it can best be seen in the example of the natural gas sector. TSI proponents argue that a well-functioning market - i.e. one that is diversified and flexible in terms of sources/supply routes - will help the European Union resist pressure from external political entities (Kořan -Wiśniewski Strážay 2017). Nevertheless they point out that the initiative remains a regional declaration whose economic and infrastructural aims are still unrealised. 
In sum, it is important to understand the Three Seas Initiative as simply an informal forum that was set up to promote closer cooperation in the energy, transport, business and digital communication sectors. Against this backdrop, it is seeking to strengthen political ties and develop joint macro-regional projects.

\section{The role of the United States in Three Seas Initiative policies}

It has been speculated that President Trump's policy towards Russia took shape at his meeting with the representatives of 12 countries from Central and Eastern Europe in Warsaw in 2017. The White House has underscored that the US wants to be part of the emerging energy market that will connect countries from the Baltic, Black and Adriatic sea regions with Western Europe. America's participation in the initiative will give it further opportunities to export oil, gas and other raw materials and thus lead to greater revenue and world influence. This, of course, corresponds with the energy policy of the Polish government, which hopes to abandon Russian gas and replace it with American supplies, a move that would also benefit Central Europe. The goal here is to ensure energy security so that no one can "blackmail" the countries in this part of Europe, as Polish President Andrzej Duda has put it (Dongmiao 2017). Poland's plans also include contracts for American arms in order to modernise the Polish army (Kauffmann 2017).

What has brought these countries together in this political and economic initiative is pressure from the aggressive policies of the Russian Federation. Following the annexation of Crimea and Russian military aggression towards Ukraine, states such as Poland, Lithuania, Latvia, Estonia and Romania have felt an increasing need to strengthen their strategic partnerships with the United States (Milewski 2017: 82-93).

At the same time, there is less agreement between Poland and the Czech Republic, Hungary and Slovakia about the threat posed by their eastern neighbour. These four countries have, however, cooperated effectively on other areas of EU policy such as the migrant crisis. Poland has discussed similar issues with the Balkan states. All this supports the view that Poland could be the keystone in a discrete cooperation arrangement based on very cautious and complex diplomacy. From an economic standpoint, there are extensive similarities among these countries.

Although the Three Seas Initiative only concerns limited safety issues, there are clear links between strengthening the US's role in the natural gas market and the potential for greater energy security in this region. One of the initiative's main goals is the promotion of greater energy independence from Moscow, which has sometimes used gas and oil as political tools. Russia imposes its will on its neighbours in part through its control of energy supplies. Many Eastern European countries are poor in energy resources and thus fear that 
they could face a sudden interruption of supplies. The Kremlin has also used its energy pipelines in Eastern Europe to apply "economic blackmail" to the European Union, which depends on Russian energy (Investor's Business Daily 2017). This was made clear during the 2009 Russia-Ukraine conflict, which led to the cessation of gas supplies to Europe and caused a serious crisis. Given this background, it is hardly surprising that the nations in this region, which rely on Russia for most of their energy, want independence from this supplier.

Importantly, the US President's presence in Warsaw also had implications for economic policy, particularly in relation to Germany. Together with the Russian company Gazprom, two German companies, BASF and E.ON, built the Nord Stream 1 gas pipeline, which transports gas from Russia to Germany and bypasses Poland and Ukraine. The construction of a second pipeline, Nord Stream 2, is currently being planned. Most of Central and Eastern Europe is concerned that energy supplies across Europe will increasingly depend on Russia (Krupa 2017).

As the site of an LNG terminal, Poland has the potential to supply the region and thus help develop the gas market and improve its competitiveness and security. According to some estimates, this terminal is so large that it could replace up to $80 \%$ of Russian gas supplies to Poland. All three Baltic states are also building LNG installations and Croatia plans to launch its own LNG terminal in 2019 (Investor's Business Daily 2017). Moscow, thus, stands to lose its energy monopoly and may even have to surrender some of its interests, which could force the Kremlin to compete from a price standpoint.

In 2017, the first LNG shipment from the US was delivered to Świnoujście, a Polish port on the Baltic coast. This approach could potentially be used for gas supplies to Croatia and other countries south of Poland. Such a solution may well align with the efforts of the Trump administration to export American gas (Gera 2017; cf. Cabada - Waisová 2018: 15-16).

\section{Characteristics of the Three Seas Initiative countries as of 2017}

There are, it turns out, important differences among the Three Seas Initiative countries, and these are reflected in the pace of the transformations they underwent in the 1990s. In this respect, the key variable is the extent of each state's involvement in political democratisation and economic liberalisation. Difficulties during the transformation period, including the dramatic events in the Balkans, affected the speed of socio-political and economic evolution. One illustration of this is the differing stances of individual governments on the adoption of the single euro currency and entry into the Schengen area. Geographical location is another important factor that has shaped perspectives on political, economic and military alliances. All these countries belong to the EU and all but Austria are NATO members. As such, they share a general strategy 
based on their membership of these organisations. Nevertheless, each one has different perceptions of its relations with other states (Ruszkowski 2015: 9-25).

The TSI states can be divided into five groups based on the above political transformation process, which has largely determined the stage of their accession to European structures. Also significant are the geopolitical forces that have shaped each state's political strategies.

The first group consists of the Baltic states, namely Lithuania, Latvia and Estonia, which, given their small and very open economies, are susceptible to external shocks. These economies still depend on the inflow of foreign direct investment to finance production and maintain economic growth. Their relations with Russia may continue to affect trade. These states also have ongoing issues with national minorities, especially the large Russian community which is the dominant population in some regions. There are fears and doubts about this community's loyalty to authorities in Tallinn, Riga and Vilnius.

The second group contains Poland, the Czech Republic, Slovakia and Hungary, i.e. the countries of Visegrad Group, which is the basis for the Three Seas Initiative. These countries are seen as models of political transformation and the Europeanisation of former Eastern bloc countries. Visegrad Group countries are generally considered safe for those coming from abroad, whether as immigrants or tourists. There is a small risk of terrorism from domestic or international entities. At the same time, these countries face major threats because of their use as transit places by drug and human traffickers.

Due to the migrant crisis, anti-migrant sentiments have been running high in the Visegrad countries, increasing the risk of right-wing extremist attacks on migrants and national minorities. Right-wing extremist parties have also been making their presence felt in the public sphere, which may lead to political instability in the long run.

Like Slovakia and Hungary, Poland is a neighbour to Ukraine and has, thus, been exposed to growing regional tensions in response to Russia's annexation of Crimea and ongoing military operations in eastern Ukraine. As members of NATO since 1999 (or 2004 in the case of Slovakia) and the EU since 2004, the Visegrad states have come to cooperate more closely with the world's most developed economies and international security organisations. Nevertheless, their military equipment remains obsolete and in need of modernisation.

The third group comprises Bulgaria and Romania, whose membership of NATO since 2004 and the EU since 2007 has led to greater cooperation with international institutions on economic and security policies. At the same time, the location of these states between Europe and Asia means they are attractive transit zones for illegal goods and immigrants entering the EU. A large number of organised crime groups have been noted in these countries though no terrorist groups have been reported. From an economic innovation perspective, 
corruption remains a serious problem that undermines the rule of law and state transparency. Bulgaria and Romania also face major challenges around the operation of, and trust in, state protective services such as the police and the modernisation of the army. Cybersecurity and data protection are also key problems, with users exposed to potentially huge losses via modern technology.

Two countries from the Balkan region make up the fourth group of political actors. Croatia has increased its stability and security since joining NATO in 2009 and becoming an EU member in 2013. The country is troubled, however, by persistent tensions caused by the presence of the Serb minority on its territory, which could lead to an outbreak of ethnic violence, especially in the Vukovar region. A border dispute with Slovenia is another unresolved problem.

The second Balkan country in this group is Slovenia. Accession to both the EU and NATO in 2004 has strengthened this state's economic cooperation with EU members. Croatia and Slovenia have each also received EU funds to enhance their cybersecurity capabilities. The Adriatic Basin, however, remains an attractive destination for international drug and weapon traffickers.

The fifth group includes only one state, Austria, which is also the sole Three Seas Initiative member that was not part of the Eastern bloc before 1989. Other distinguishing factors are the fact that it is not a NATO member and has been an EU member since 1995. Since that time, Austria has received significant EU funds which it has invested in rail infrastructure and housing. It is also one of the few Central European countries to set ambitious targets which should further increase its share of renewable energy sources. Austria's energy policy benefits from a well-developed transmission network, which supports low electricity prices. The country is also noteworthy for its geographical location, which makes it an important hub between Central and Western Europe.

\section{Cybersecurity challenges for the Three Seas Initiative as of 2018}

As information and communications technology (ICT) has developed, it has played an increasing role in international politics. The new digital era is characterised by the dependence of the state, its citizens and its economy on cybertechnology. As such, the conditions for building an alliance based on ICT networks are of concern to many countries including those in the Three Seas Initiative. Such a project could strengthen both the economies and the cybersecurity of Central and Eastern European countries (The Digital 3 Seas Initiative: A Call For a Cyber Upgrade of Regional Cooperation 2018).

As originally conceived, the Three Seas Initiative was meant to focus primarily on the development of energy and transport infrastructure. It is now safe to assume, however, that this political venture will extend in the near future to digital technology including fibre optics, broadcasting stations and the 5G network. The project will, thus, be complemented by work on digital connec- 
tivity, which is now a condition for economic development. This will ensure faster, uninterrupted and more secure connections for devices and installations within the Internet of things that could include smart cities, autonomous cars, drones and robots. If supplemented by cybertechnology, optical fibre networks could also help eliminate gaps in the TSI communications infrastructure used to connect with other EU countries. The implementation and success of this project are, thus, important not only for the countries in the region but also for the cohesion of the EU.

At the same time, it must be said that security policies and cybertechnology have limited development potential in the Three Seas Initiative states. This is especially clear when we consider the social context of these countries compared with conditions in the United States, Russia, China and the entire EU.

Table 1: Population and number of Internet users within the Three Seas Initiative states; comparison with selected locations in 2018

\begin{tabular}{|c|c|c|c|c|c|}
\hline & TSI states & EU & Russia & USA & China \\
\hline Population & $111,575,906$ & $506,279,458$ & $143,964,709$ & $363,224,006$ & $1,415,045,928$ \\
\hline Internet users & $83,620,538$ & $433,651,012$ & $109,552,842$ & $320,059,368$ & $772,000,000$ \\
\hline $\begin{array}{c}\text { Internet users } \\
\text { in the popula- } \\
\text { tion (\%) }\end{array}$ & 74.9 & 85.6 & 76 & 88.1 & 54.6 \\
\hline $\begin{array}{c}\text { Internet users } \\
\text { in TSI states } \\
\text { compared to } \\
\text { users in other } \\
\text { countries/re- } \\
\text { gions (\%) }\end{array}$ & $\mathrm{n} / \mathrm{a}$ & 19.2 & 76.3 & 26.1 & 10.8 \\
\hline
\end{tabular}

Source: Author's own calculations based on the EU report Power from Statistics: Data, Information and Knowledge - Outlook, available at: https://ec.europa.eu/eurostat/en/web/products-statistical-reports/-/ KS-FT-18-005 (8 March 2018).

The number of Internet users within a population shows the scale of the digitisation process under way in that society. In this context, the number of Internet users in the Three Seas Initiative states is lower than the equivalent figure for the European Union or countries like the US and China. Of course, this gap reflects not only the level of IT development in a specific society but also the fact that some non-TSI states have a huge number of citizens. Regardless of population size, however, the dominance of cyberspace in everyday life does not only suggest a high degree of innovation and cybertechnology absorption. It also points to a high level of vulnerability to harmful cyber incidents in the public sphere.

In this regard, the data on Internet user numbers has particular significance for the security policies of the Three Seas Initiative countries. A social group based in the virtual world may also be understood as a number of citizens who 
are susceptible to social engineering in cyberspace. Information technology plays an important role not only in gathering information, as was seen in the Facebook data crisis caused by Cambridge Analytica, but also in the harnessing of disinformation techniques. For a clear illustration of this phenomenon, we need only look to the use of cyberspace for social engineering during the 2016 US presidential election campaign.

Popular social media can influence public opinion. Since, however, the same information will not meet with the same reaction in all nations, each problem needs to be solved individually. Each state has its own cybersecurity culture and its own political culture. This means there will be different degrees of sensitivity to specific information across both the real world and cyberspace.

In this context, we should bear in mind that the Central and Eastern Europe area is of great importance from the point of view of the influence and operations of global powers. From the perspective of neighbouring Russia, this region represents the external border of the EU and NATO. As a result of Moscow's expansionist policies in both the conventional and digital senses, the TSI states have come under political and economic pressure. The alliance of 12 Central and Eastern European countries may, thus, be seen as an attempt to deepen security cooperation in response to new threats in the region, including hybrid threats, which are becoming increasingly difficult to identify. Among these threats are cyber incidents, which are targeted at specific social groups and critical state infrastructure.

\section{Table 2: Most frequently reported cyber incidents in Three Seas Initiative countries in 2018}

\begin{tabular}{|l|l|}
\hline $55.5 \%$ & Computer fraud \\
\hline $12.3 \%$ & Offensive and illegal content \\
\hline $10.9 \%$ & Malware \\
\hline $5.6 \%$ & Hacking attempts \\
\hline $3.3 \%$ & Data gathering \\
\hline $2.8 \%$ & Hacking \\
\hline $23 \%$ & Attacks on resource availability \\
\hline $2.3 \%$ & Data security attacks \\
\hline $4.7 \%$ & Other \\
\hline
\end{tabular}

Source: Author's own calculations based on computer emergency response team (CERT) reports in Three Seas Initiative states.

In fact, cyber threats have become a key aspect of state security policy. Malicious cyberspace campaigns are directed at vital infrastructure and can disrupt economic activities and even national security. They may, thus, pose a real threat to the lives of citizens. On this basis, there is a need to strengthen regional 
cybersecurity. This could be done, for example, through educational initiatives, expert exchanges, training, drills and in-depth cooperation between computer emergency response teams.

Reports of cyber incidents show not only the extent of the cyber threats facing each state but the fact that private organisations are struggling with these issues as well. These reports also highlight the wide spectrum of possible cyber threats.

These cyber incidents include what is broadly understood as information manipulation. Such cases may involve hate speech and content about social groups who are seen by their attackers as foreign and hostile. In the Central and Eastern European context, these messages have often expressed negative emotions around the Hungarian diaspora in Romania and Slovakia. A second conflict that has been politically exploited in cyberspace is the one between the Poles and the Ukrainians, whose doubts and lack of trust around one another are said to stem from a tragic history. More recent, there has also been a rise in anti-immigrant attitudes as a result of fears of the wave of refugees coming from Africa and the Middle East. Anti-immigrant campaigns, which have spread widely online and whose authorship has been attributed to Russia, can be assumed to be part of a Kremlin policy that actively targets the Three Seas Initiative states. All these forms of disinformation are attacks on the cohesion of projects implemented in Central and Eastern Europe.

The digital cooperation of the Three Seas Initiative countries faces four main challenges. The first of these is the need to pursue the common interests of these countries while also addressing and achieving EU policy goals. The second relates to the implementation of existing EU projects such as the Digital Single Market, the "Connecting Europe" financial tool, permanent structural defence cooperation (PESCO) and the European Defence Fund. The third challenge concerns ensuring the data security of both state and private institutions. Given the region's key role as the eastern flank of NATO, this issue should be a cybersecurity policy priority for TSI states, especially in the face of growing Russian activity.

The fourth and final challenge relates to the development of an international security policy that will use the eastern part of NATO to enhance actions against hybrid threats. This approach is also justified by the fact that Central and Eastern Europe is home to NATO specialist centres in this area. The latter include the Cooperative Cyber Defence Center of Excellence in Tallinn, the Counter-Intelligence Centre of Excellence in Krakow and the Strategic Communications Centre of Excellence in Riga.

For a better understanding of cybersecurity policies in this region, it is worth looking at the data from individual states concerning their defence-related spending. As we will see, these countries each have different security policies and different interpretations of cyber threats, which are reflected in their defence budgets. 
Table 3: Population, Internet user numbers and defence spending in Three Seas Initiative countries in 2018

\begin{tabular}{|l|l|l|l|l|l|l|c|}
\hline Country & $\begin{array}{l}\text { Popula- } \\
\text { tion }\end{array}$ & $\begin{array}{l}\text { Internet } \\
\text { users }\end{array}$ & $\begin{array}{l}\text { Internet } \\
\text { users in } \\
\text { the popu- } \\
\text { lation (\%) }\end{array}$ & $\begin{array}{l}\text { GDP } \\
\text { (USD) }\end{array}$ & $\begin{array}{l}\text { Defence } \\
\text { spending } \\
\text { as a share } \\
\text { of GDP } \\
(\%)\end{array}$ & $\begin{array}{l}\text { Defence } \\
\text { budget } \\
\text { (USD) }\end{array}$ & $\begin{array}{l}\text { Cyber- } \\
\text { security } \\
\text { spending } \\
\text { as a share } \\
\text { of defence } \\
\text { budget } \\
\text { (\%) }\end{array}$ \\
\hline Lithuania & $2,830,582$ & $2,399,678$ & 84.8 & $42.8 \mathrm{bn}$ & 1.96 & $642 \mathrm{~m}$ & 4.9 \\
\hline Latvia & $1,944,565$ & $1,663,739$ & 85.6 & $27.9 \mathrm{bn}$ & 2 & $411 \mathrm{~m}$ & 4.7 \\
\hline Estonia & $1,305,755$ & $1,196,521$ & 91.6 & $23.5 \mathrm{bn}$ & 2.14 & $503 \mathrm{~m}$ & 6.0 \\
\hline Poland & $38,563,573$ & $28,267,099$ & 73.3 & $467 \mathrm{bn}$ & 1.98 & $9.08 \mathrm{bn}$ & 5.8 \\
\hline $\begin{array}{l}\text { Czech } \\
\text { Republic }\end{array}$ & $10,555,130$ & $9,323,428$ & 88.3 & $194 \mathrm{bn}$ & 1.11 & $1.97 \mathrm{bn}$ & 3.7 \\
\hline Slovakia & $5,432,157$ & $4,629,641$ & 85.2 & $90.3 \mathrm{bn}$ & 1.20 & $983 \mathrm{~m}$ & 3.9 \\
\hline Hungary & $9,787,905$ & $7,874,733$ & 80.5 & $117 \mathrm{bn}$ & 1.08 & $996 \mathrm{~m}$ & 3.6 \\
\hline Bulgaria & $7,045,259$ & $4,213,065$ & 59.8 & $50.4 \mathrm{bn}$ & 1.56 & $678 \mathrm{~m}$ & 4.3 \\
\hline Romania & $19,237,513$ & $12,082,186$ & 62.8 & $187 \mathrm{bn}$ & 1.93 & $2.78 \mathrm{bn}$ & 5.4 \\
\hline Slovenia & $2,071,252$ & $1,563,795$ & 75.5 & $44.1 \mathrm{bn}$ & 1.01 & $450 \mathrm{~m}$ & 2.9 \\
\hline Croatia & $4,209,815$ & $3,133,485$ & 74.4 & $49.9 \mathrm{bn}$ & 1.30 & $588 \mathrm{~m}$ & 3.7 \\
\hline Austria & $8,592,400$ & $7,273,168$ & 84.6 & $387 \mathrm{bn}$ & 0.7 & $2.31 \mathrm{bn}$ & 2.6 \\
\hline
\end{tabular}

Source: Author's own calculations based on the defence spending of TSI states on cybersecurity research and development. Figures are also drawn from interviews with national cryptology centre and counter-intelligence personnel and security reports from these countries.

As Table 3 shows, there are significant differences among Three Seas Initiative countries such as Lithuania, Latvia, Estonia, Poland and Romania when it comes to their defence budgets and cybersecurity outlays. The reasons for this probably relate to the subjective sense of threat, degree of proximity to the Russian Federation and level of anti-Russian feeling in some Central and Eastern European nations compared with the situation in Western European countries (Usakovs - Grybauskaite 2018). Cybertechnology has, thus become a factor which shapes strategic and economic policy ideas. Ironically the challenge here is not only cyber threats but also the dynamic transformation of key aspects of the economy and state management, which the legal and education sectors must keep up with.

Given the dense network of interconnectivity, cyberspace has a crucial part to play in strengthening the economy and developing and implementing state policies. It also shapes how authorities connect with citizens when providing services and how governments approach diplomacy. 
The digital transformation of the Central and Eastern European economies is sure to affect the role of cyberspace in international relations. It will also produce new hybrid cross-border security threats. This means that the Three Seas Initiative will need to have a strong digital dimension. Attention to cybersecurity is, thus, indispensable for the development of this project.

\section{Different interests of the Three Seas Initiative states}

Internal policies that could supersede foreign policy projects threaten the political cohesion of the Three Seas Initiative countries. Since the TSI involves presidents serving as patrons for sectoral cooperation, there are questions about the possibilities for action in areas that come under the power of governments (Gniazdowski 2017: 105-108). In particular, if two executive officers, i.e. the president and the prime minister, come from opposing ideological camps, then the competition between them could paralyse decision-making and destabilise national policy. A similar phenomenon may occur if elections lead to a change of power and the new president does not feel obliged to continue previous arrangements (Milewski 2017: 82-93). Any political project that focuses on a country's stated goals is, in short, vulnerable to political changes resulting from elections.

In order to answer the question that we posed at the outset, i.e. whether the Three Seas Initiative could potentially achieve its expressed goals, we need to consider the different interests of participating countries. It may indeed turn out that each member has its own strategic interests which conflict with the directions chosen by other states (Milewski 2017).

In this context, differences of interest may exist at two levels. The first concerns the current interests of a given government, that is, economic concerns such as energy transmission. The second level relates to beliefs about the common fate and definition of Europe and long-term threats. Clearly the elites of individual countries may take different positions on a specific international phenomenon or event. One important element in the success of any political venture will be the geographical location of participants since this gives rise to certain natural areas of cooperation. The countries that make up the Three Seas Initiative do not represent a political monolith. Rather, the project involves groups and countries, some of which have very different interests both within the EU and in their relations with non-EU countries (Ruszkowski 2010: 97-110).

In this regard, it is difficult to look past the conflicting ambitions of individual countries in this region. A clear example is Serbia, which was not invited to the Warsaw summit because of its animosities with Croatia. This absence of Serbia, a non-EU member that is not particularly welcomed by its neighbours, has a huge impact on Croatia's potential for connections with Romania and Bulgaria. Similarly, there is little chance of a straight-line link between Romania 
and Poland because Ukraine lies between these states. Not all TSI members are willing to cooperate with Ukraine, and this cooperation is difficult owing not only to Ukraine's lack of EU membership but also the ongoing war.

Croatia and Slovenia are locked in a border dispute. The latter is about minor adjustments to a 2.5-mile sea corridor in the Bay of Piran. Nevertheless, in the Balkans, where the wounds of the 1990s are still unhealed, even a dispute of this kind provokes heightened emotions (Kokot 2017: 3). In Croatia, the topic has been widely discussed, and people recall that Slovenia blocked Croatia's EU accession for years on account of this very border issue. The situation has been exacerbated by the 2017 verdict of a Dutch arbitration tribunal, which found in Slovenia's favour. Zagreb has said that it does not intend to recognise the verdict.

The Czechs have been eyeing the Three Seas Initiative suspiciously and note that it brings to mind old ideas of Poland as a great power and offers them no benefits. The Czech government realises that the country's economic growth depends on EU subsidies (Ehlem 2017: 14). The Slovaks have taken the same position and do not want to be associated with this project. Slovakia is a member of the euro currency area, and the European Union is the driving force behind its development. No government in Bratislava will opt to loosen relations with the EU (Ehlem 2017), and not everyone is ready to invest in America as the sole security guarantor. As participants in the monetary union, Slovakia and Slovenia are mainly concerned with participating in integration processes inside the euro currency area. Similarly, the Czechs have prioritised their relations with Germany over those with the US.

Romania is, on the other hand, basing its security policy on US positions. The Romanian government has already agreed to the installation of parts of the US Ballistic Missile Defense System on Romanian territory at Deveselu. It also wants to increase the size of the US deployment to the country. One potential plan is to purchase a US Patriot missile system while at the same time developing cooperation with the German and French arms industries. Romania is also supposed to create a joint land forces brigade with the Czechs, the Germans and the French (Kokot 2017: 3). In the political and economic domains, however, Bucharest's preference is for an alliance with Berlin and Paris, and it has been treating the Three Seas Initiative as supplementary.

Hungary is a different case, and it has been boosting its energy security based on gas supplies from Gazprom and nuclear energy-related cooperation with Russia (Parafianowicz 2017: A2). The Hungarian government has been striving to diversify the country's energy supplies while also concluding new agreements with the Russians. The current contract with Gazprom expires at the end of 2021. Budapest is hoping to force a price decrease from the Russian giant by seeking out other sources. Even so, it continues to support plans for the alternative Black Sea route that Russia wants to build in cooperation with Turkey (Kokot 2017: 3). 
Austria has meanwhile been distancing itself from the initiative promoted by Poland. Like the Czech Republic, it did not send a presidential representative to the Three Seas Initiative Warsaw summit. Vienna has no interest in supporting Warsaw's energy proposal. Like Hungary, Austria is a Gazprom customer and it sees Russia as a reliable partner that sells its raw materials at a competitive price. In contrast, Croatia has shown the greatest enthusiasm for the Three Seas Initiative. It has invested in an LNG terminal on Krk island near Rijeka and joined in liquefied gas trading with Poland (Parafianowicz 2017: A2).

Like Austria, Bulgaria has stepped away from the project. It refused to take part in joint fleet operations with Romania and Ukraine, fearing its participation might irritate Russia. Boiko Borisov's government has been trying to manouevre between the West and Russia, which still enjoys great influence in the country, especially when it comes to energy. Bulgarian parliament was even prepared to approve the construction of the South Stream pipeline that would have bypassed Ukraine. The issue was laid to rest, however, after the European Commission intervened and it was revealed that a South Stream construction bill introduced by one Bulgarian MP had been drafted by Gazprom's lawyers.

Following his criticisms of the Kremlin's activities in the Ukrainian Donbas, former Bulgarian president Rosen Plevnijew was not nominated by his party to stand for re-election. When the socialist candidate and former aviation commander Rumen Radev won the election in January 2017, he did not hide his sympathies with Russia. It was soon revealed that Poland would not be repairing Bulgaria's MiG aircraft; that task fell to Russia, whose bid had been more expensive.

The Baltic states have the greatest fears of Russian aggression, and they may prove to be real allies in the Three Seas Initiative. These countries are looking for alternative energy suppliers and would prefer to maintain a strong relationship with the EU. Estonia has been in the euro currency zone since 2011 while Latvia joined in 2014 and Lithuania in 2015. The Lithuanians signed on despite the fact that politicians in Vilnius believed this was a premature move economically. Ultimately, however, they went ahead because they saw this as an additional guarantee of security against potential Russian aggression (Kokot 2017: 3).

\section{Conclusion}

The importance of the Three Seas Initiative for European countries is still being discussed and these debates will certainly continue for years to come. We may expect that each state will put its own spin on this discussion based on its national interests and foreign policy. Undoubtedly there are many questions about the relations among the states involved in this project. Nevertheless, these countries are connected by a desire to modernise and catch up with more developed regions of the European Union. The Three Seas Initiative will surely not obstruct this goal. 
Along with a consistent communications policy, the TSI is in need of funding. Negotiations on the next multi-year EU budget start in 2018. If they unite, the TSI countries may be more successful when fighting for funding for the initiative in Brussels and trying to secure external investors. However, for this project to become a reality, the states that attended the 2017 Warsaw meeting will need to make some difficult decisions and take decisive action. In this regard, three types of political actions are needed. First, the countries in the TSI region must agree on their joint project priorities and lobby for funding for these projects in the EU. Second, the TSI region must set up a business forum that can be a first contact point for external investors; this forum should be promoted in Brussels and Washington. And third, the European Union and its member states must take steps to improve cross-border infrastructure that will enable investment support. Without these three steps, the Three Seas Initiative will have difficulty in attracting the external investment needed to translate visions of infrastructure into actual projects (Jones 2017: A10).

A year after the announcement of cooperation among the leaders of 12 Central European countries in Dubrovnik, a grand idea has been adapted to reflect the more modest reality. Poland, the main architect of the Three Seas Initiative, has had to limit its ambitions. Hopes for the extension of cooperation to non-EU countries, particularly Ukraine and Georgia, have been abandoned. Their membership of the group is opposed by TSI countries which have good relations with Russia and do not intend to change this. At the same time, the Visegrad states have blocked the introduction of non-EU Balkan countries such as Montenegro (Wroński 2017: 3).

One key challenge that may also be the source of many problems at European level is the need for EU member states in the Three Seas Initiative to reconcile their relationships with the major EU players France and Germany. It is hard to imagine that decision-makers in Bucharest, Prague, Bratislava and Sofia will always put relations with Warsaw ahead of those with Paris, Berlin and Brussels. The latter are after all the main drivers of the modernisation of these countries and their consolidation in the EU.

\section{References}

Cabada, Ladislav (2018): Visegrad Group in the Context of Other Central European Cooperation Formats. Politics in Central Europe 13(2): 165-179, doi: 10.2478/pce-2018-0006.

Cabada, Ladislav - Waisová, Šárka (2018): The Visegrad Four as an ambitious actor of (Central-) European foreign and security policy. Politics in Central Europe 13 (2): 9-20, doi: 10.2478/ pce-2018-0014. 
Corneliu-Aurelian, Colceriu (2017): Iohannis: Romania wants to make Three Seas Initiative summit more visible; it is a profoundly pro-European initiative. Tribune Content Agency Regional News Chicago, 3 October.

Ehlem, Mark (2017): Neighbours look suspiciously at Warsaw. Gazeta Wyborcza, 23 June,14.

Gera, Vanessa (2017): Trump visit spotlights Three Seas plan for more energy ties. The Seattle Times, 5 July.

Gniazdowski, Mateusz (2017): Comments on the Structure of the Three Seas Initiative and the Warsaw Summit. The Polish Quarterly of International Affairs 26(2): 105-108.

Investor's Business Daily (2017): Can Trump Use Fracking to Break Putin's Stranglehold On Eastern Europe? (6 July), available at: https://www.investors.com/politics/editorials/can-trump-use-fracking-to-break-putins-stranglehold-on-eastern-europe/ (12 February 2018).

Jones, James L. (2017): Chances Three Seas Initiative. Rzeczpospolita, 3 July, A10.

Kauffmann, Sylvie (2017): Donald Trump à Varsovie pour redorer son blason européen. Le Monde, 5 July.

Kokot, Michat (2017): What does Three Seas Initiative want from Donald Trump? Gazeta Wyborcza, 6 July, 3.

Kořan, Michal - Wiśniewski, Bartosz - Strážay, Tomáš (2017): Myths around Three Seas Initiative. Rzeczpospolita, 6 July.

Krupa, Matthias (2017): Trump umgarnt die Polen. Die Zeit, 28 June.

MacDowall, Andrew (2013): Poor roads blight bridge over Danube. Financial Times, 18 October.

Milewski, Oktawian (2017):Romania and the Three Seas Initiative: Bucharest, 2018 Summit Host, The Polish Quarterly of International Affairs 26/2: 82-93.

Parafianowicz, Zbigniew (2017): Promises solidarity and will go to Putin. Dziennik Gazeta Prawna, 6 July, A2.

Pavlovets, Yuri (2017): Croatian president assures Putin that Three Seas Initiative isn't anti-Russian, EA Daily, 20 October: https://eadaily.com/en/news/2017/10/20/croatian-president-offers-russia-joining-anti-russian-program (12 February 2018).

President of the Republic of Poland (2017): Three Seas summit has built ties among CE countries, 6 July, http://www.prezydent.pl/en/news/art,496,president-three-seas-summit-has-built-ties-among-ce-countries.html (12 February 2018).

Ruszkowski, Janusz (2010): Supranationalism in the European Union's political system, Warsaw.

Ruszkowski, Janusz (2015): European theories in search of the European Union's final political purpose, in Wojnicz, L. - Rdzanek, D. - Potkańska, M., eds., In search of the final political purpose of the European Union, 9 -27, Institute of Political Science and European Studies at the University of Szczecin, Institute of European Studies of the University of Warsaw.

Ruszkowski, Janusz (2017): Bypassing states in the European Union's system of multi-level management, in Ruszkowski, J - Podgórzańska, R. eds., A state in the European Union, University of Szcecin. 
The Digital 3 Seas Initiative: A Call For a Cyber Upgrade of Regional Cooperation (2018): The Kosciuszko Institute Policy Brief, June 2018, available at: https:/www.globsec.org/wp-content/ uploads/2018/06/WHITE_PAPER_The-Digital-3-Seas-Initiative_GLOBSEC.pdf (1 October 2018).

Usakovs, Nils - Grybauskaite, Dalia (2018): Highlights from Baltic Russian-language media 22-28 Jan, BBC Monitoring European, 1 February.

Wiśniewski, Bartosz (2017): The Three Seas Initiative after the Warsaw Summit: What Next? The Polish Quarterly of International Affairs 26/2: 55-64.

Wroński, Pawet (2017): Three Seas Initiative: From great idea to modest reality, Gazeta Wyborcza, 6 July: 3.

Xinhua (2017): Trump hails Three Seas summit, 6 July, available at: http://www.xinhuanet.com/ english/2017-07/06/c_136423078.htm (12 February 2018).

Marek Górka is a graduate of the Political Science Department at Nicolaus Copernicus University in Toruń, Poland. He is an assistant professor in the Faculty of Humanities of Koszalin University of Technology in Poland and has published on subjects including the Israeli and Polish intelligence services and cyberbullying among children and young people. His research interests include security policy, cybersecurity, terrorism, intelligence and counter-intelligence services, Internet sociology, electoral competition and charismatic leadership.E-mail: marek_gorka@wp.pl. 